\title{
Applying AHP Application To Determine The Risk Of Supply Chain And The Effect On The Price Of Fish In Ports Central Sulawesi
}

\author{
StefiSilfia Sari Makalew ${ }^{1}$, Ponisri ${ }^{2}$, Siti Fatimah ${ }^{3}$ \\ ${ }^{1,2,3}$ Tadulako University \\ School of Management, Faculty of Economics and Business, Palu \\ Central Sulawesi Province, GPO BOX 94118, Indonesia
}

sarimakalew@gmail.com, ponisri585@yahoo.co.id, sitifatimahj@yahoo.co.id

\begin{abstract}
Purpose: To describe the risks in Supply Chain Management that can affect the ports of central Sulawesi. Design/Methodology/Approach:This study uses a research ection approach so that researchers were able to identify the over all risk ofthe supply chain of fish in the ports. This research was also supported by the operating menajer and other stakeholders. Using AHP tool to determine the highest risk. Result: The risks faced in the supply chain of fish in the ports of Central Sulawesi is the weather, quality, partners, and

transportation.

Originality/Value:This study to provide insight to the general public about the rise in the price of fish. As well as, provide information on the organization or company that isengaged in the businessof fish.
\end{abstract}

Keywords: SupplyChain, Risk, AHP, Weather, andQuality.

\section{INTRODUCTION}

Geographically, the State Indonesia is located between two continents (Asia and Australia) and two oceans (Indian and Pacific).Indonesia is counted a archipelagic nation with two-thirds of the oceans is greater than the mainland, with the potential of natural and abundant wealth which has an area of 7.7 million $\mathrm{km}^{2}$, the longest coastline in the world's 4th $+95,181 \mathrm{~km}$ and 13.66 island (national Freezing RBI , 2010). Data Food and Agriculture Organization (2012) Suggests that Indonesia currently ranks third in the world's largest fishery production under china and india, only about $10 \%$, which has been exported and used it is the most dynamic regionin the constellation of the world both economically and politically. The uniqueness of the geographical location puts Indonesia has a high dependence on marine sector, as well as the province of Central
Sulawesi. therefore, it is logical that the marine economy made a footstool for national economic development.

Central Sulawesi is a unique area with dominated by mountains and hills have steep slopes that form a valley in the coastal area. Land area is $63305 \mathrm{~km} 2$ or Central Sulawesi $6,330,466.82$ hectares or $\neg 36,47$ percent total the area island of Sulawesi and Central Sulawesi seareached 193,923.75 km2. Central Sulawesi astronomical positions located between the 2022 'North latitude and 3048' south latitude and 119022 'and 124 022' East Longitude (source: Bappeda Central Sulawesi). Central Sulawesi geostrategic position in the middle of the archipelago and in the middle of the island of Sulawesi, located in the path of the water corridor from north to south towards the Pacific Ocean (Makassar Strait and Celebes Sea).

Central Sulawesi province, a mountainous region and the highlands and lowlands which are in the valley and is in the Coast. Land area of Central Sulawesi province is 68033 $\mathrm{km}^{2}$ or $35.96 \%$ of the size of the island of Sulawesi and marine seacovering 193,923.75 $\mathrm{km}^{2}$. Geographically, Central Sulawesi province lies between $2{ }^{\circ} 22^{\prime}$ North latitude and $3048^{\circ}$ south latitude and $119^{\circ}$ and $124^{\circ} 22^{\circ}$ $22 `$ east longitude.

Central Sulawesi province has done acceleration to facilitate trade by making port. One port of the very important role in supporting the distribution and movement of goods in the province of Central Sulawesi is the Port Pantoloan. Currently Pantoloan port has an important role for the company because the port Pantoloan the only active port and place of national and international distribution.

This study aims to determine the risk of warehousing fish in the Central Sulawesi determine the effect of the rising price fish. Fish prices were low level, Information fluctuations in the price of fish is obtained by requesting 
confirmation from the company processing fish in Central Sulawesi, located close to the port.

The allocation of fish warehousing in Central Sulawesi province needed by land or sea transport while maintaining the quality of the fish.As stated by (Prihantoro Rudy, 2012) good quality can increase its profit so as to achieve customer satisfaction. There are influencing customer satisfaction in the market that price, willingness and quality. Customers require an affordable price with good quality and willingness right time to customers. Time transport of fish that have been determined to be sent on time.

The effectiveness of the allocation of fish warehousing in the review of how the active role of the supply chain so that the company's strategy in a changing marketing uncertainty because consumers can change the They taste. Uncertainty can be prevented by increasing the quality of service quality to customers that is the role of supply chain management.

This study introduces to the public about the influence the price of fish and projects for the company in order to know what the strategy should be implemented in the company to increase profits at the company.

\section{Literature Review}

\subsection{Theory of Total Quality Management (TQM)}

Improvement of product quality, human or process in the company to achieve its goals the system of TQM (Total Quality Management). Quality is determined by the customer to meet their needs. Judging from affordable prices, security products with guaranteed quality, timeliness in ordering products. System TQM can supported by qualified resources within an enterprise. Obviously quality resources passing the name of training and education that is held by the company.

Santoso (1992) says that TQM is a management system that elevates the quality as a business strategy and customer oriented decision involving all members of the organization. According to Rudy Prihantoro (2012) Application of TQM in a company can provide major benefits which in turn increases the profit and competitiveness of the companies concerned. By improving quality on an ongoing basis, the company can increase its profit.

\subsection{Quality or Quality}

In attracting customers of course the company will pay attention to the quality or the quality of the product to be sold. Philip B. Crosby (quoted Prihantoro Rudy, 2012) suitability to the requirements covering Availability, delivery, reliability, maintainability, and cost effectiveness. Crosby is in achieving quality emphasizes the importance of involving everyone in the organization process, by emphasizing the suitability of the request or specification. Quality of a product can be guaranteed because the system automatically tries to control and prevent any potential for discrepancies or irregularities at all stages of the supply chain. It is also a positive influence on performance company, which will be avoiding wasteful spending, minimize costs, and in the end is a significant increase in corporate profits.

\subsection{Ports}

The ports is a haven yacht or ship cargo and one marine transportation plays an important role for the company in an extensive marketing system. Port of transporting goods usually have the tools to facilitate the loading and unloading of goods for interested parties such as fish-laden ship, so that the ship is need for cold storage as one of the means of distribution. Ports are very efficient to distribute the goods are loaded into other areas or other countries would get a profit and positive impact on the company and the industry to improve the profit out profits. (SulaimanMiru, 2007)

Ports pontoloan besides freight and passenger ports, port Pantoloan also a fishing port. The harbour fish in Pantoloan built around the village which livelihoods of fishermen. The ports is also close by TPI (a Demolition of fish) and some fish company that has a cold storage.It will be effective in the distribution warehousing for companies fish close to the port.

\subsection{Supply Chain}

Supply Chain Management is a strategic system of coordination of traditional business functions and the tactics across business functions within a particular company and across companies in the supply chain, for the purpose of improving the long-term performance of individual companies and the supply chain as a whole (Mentzer et. Al., 2001 ) Another understanding of supply chain management is a supply chain strategies that require the totality of the links in the chain to work together efficiently to create customer satisfaction at the end point. As a consequence the cost should be lowered and focus on value-added.

Under both definitions can be said that supply chain management is a system between business functions within an organization that plays a role in managing tasks related to meeting the needs of customers ranging from the supply of raw materials to the delivery of goods to customers. Consideration of risk in the supply chain are expected to contribute to losses that may arise in each chain in the implementation of the company's supply chain considerations referred to Supply Chain Risk Management (SCRM).

\subsection{Risk}

Every company must have a risk in business. Risk itself is an uncertainty in the possibility of doing business 
which could result in losses. The uncertainty can be derived from economic, natural and human behavior. Fish company certainly has the risk of such economic uncertainty, of course, consumer tastes sometimes erratic, consumer can be replaced with chicken or fish tempeh know. Natural risks can be met by the company of fish, if bad weather comes it will result in reduced fish suppliers. The risk of human behavior, here is more pressing in HRD itself, and therefore companies need the training and education of their employees so that the possibility of a slightly reduced risk

\subsection{Analytic Hierarchy Process}

According to Saaty in Simamora (2005: 56) Analytic Hierarchy Process (AHP) is a method to solve a complex situation is not structured into several components in a hierarchical arrangement, by giving the subjective value of the relative importance of each variable, and specify which variable has highest priority in order to affect the outcome of the situation. The main equipment of the Analytic Hierarchy Process (AHP) is to have a functional hierarchy with the main input of human perception. With hierarchy, a complex and unstructured problems resolved into their groups and organized into a hierarchical form. With AHP complex decision problems can be broken down into a manageable set of pairwise comparisons, help decision makers to arrive at the best alternative.

\section{Methodology}

This study uses a quantitative approach to operational managers interview and questionnaire with merchants retailers fish in a fish demolition. to obtain the most dominant risk causing fish prices rise, researchers used analytic hierarchy process tool and use descriptive to explain in detail the factors that cause fish prices rise, so that the consumer complaints, especially the people of Indonesia the said society most widely consumed fish after China and Australia.

\section{Result and discussion}

PT. PaluJaya Utamais one of fish warehousing in Mamboro ,Palu Central Sulawesi. The corporation do many kinds of saving, distribution and sending the fish, actually the corporation ways in freezer of cold storage.

Cold storage is used for cooling, freezing and saving of fishes or shrimps for while times or long times in certain temperature. In order, the fishes is fresh, high quality and safely for consumed by consumers.

Now, those are 4 the territory to be primary fish supplier, there are Tinombo, Poso, Ampana and ParigiMoutong. When, the capacity of sending until 12 ton suitably with the capacity of storage. The fishes are Tuna, Tengiri, Katombo, Cakalang, Bandeng, Suau, Shrimps, Roma - roma, Tongkoland Crabs. The fishes are delivered from the supplier territory with the land transportation, for example Box truck. The average of times for delivery is until 8 hours.

There are the code of delivery from supplier territory :

\begin{tabular}{|l|l|l|}
\hline NO & The Territory Name & $\begin{array}{l}\text { Capacity } \\
/ \mathrm{Kg}\end{array}$ \\
\hline 1 & Tinombo & $4.000 \mathrm{~kg}$ \\
\hline 2 & Poso & $3.000 \mathrm{~kg}$ \\
\hline 3 & Ampana & $3.000 \mathrm{~kg}$ \\
\hline 4 & ParigiMoutong & $2.000 \mathrm{~kg}$ \\
\hline \multicolumn{2}{|l}{ Total Capacity } & $12.000 \mathrm{~kg}$ \\
\hline
\end{tabular}

The Corporation buy the fishes with the maximum price until Rp. $12.000,-/ \mathrm{kg}$. The corporation make the standard adapt with the demand prices for the customer that until $\mathrm{Rp} 17.000,-/ \mathrm{kg}$.

The fishes that arrived in the corporation is selected with look of arriving and supplier, and then weighted and grouping with look of weight, arrived, kinds, size, and quality the fishes with prepare the basked and weighting. The fishes with small size when the weights are less from $200 \mathrm{~g}$ and then in $1 \mathrm{~kg}$ have 3 until 5 fishes $/ \mathrm{kg}$ and 5 until 7 fishes $/ \mathrm{kg}$. The example of the fishes with low weight areTongkol, Cakalang, Katomboand Ruma- ruma. And than the fishes with high weight when in one of the fishes until $10 \mathrm{~kg}$. The example of high weight areTuna and Tengiri.

The process of fishes cooling in cold storage with :1) The first the fishes is weighted until $10 \mathrm{~kg} ;{ }^{2)}$ turn down into basked and shake in submerged water, then bring up for through. The activity so the process washing and rinsing the fishes. ${ }^{3)}$ Prepare the empty basked cleanly for set the ice, the fishes formatted with the lining and formatted orderly. This is in order that keep the fishes quality, and than the fishes are not depraved and broken, the fishes is layered by bold ice. For keep the quality of fishes needed counting accurately with use ratio ice and fishes are $1: 1$. Arranging have the function as chilling, when more bold of ice so, more long times the cooling process. ${ }^{4)}$ The last save the fishes in the cold storage. For one cold storage only can be used until 5 ton. While of process, the fishes must be protected from sun light and the hard treatment can make the fish broken. if were inevitable that happens will cause both quality and price decreases.

Fish handling process is completedafter, PT. Palu Jaya Utama The main distribute the fish to Surabaya and merchants retail need. usually fish stocks in PT. Palu Jaya Utama empty main certain months, due to constraints such as bad weather and difficult fuels can inhibit the activity of fishing in the ocean.

Weather conditions greatly affect the process of fishing operations. With the weather changing fishermen will certainly complicate the conduct fishing operations. When bad weather, high waves and strong winds will hamper fishing and complicate the process of fishing, because 
fishermen still use boats that the facilities are limited. Fishermen stop fishing temporarily, in order to avoid the occurrence of marine accidents resulting from extreme weather. Even if forced to go to sea, the fish catch is not worth the cost incurred. Similarly, the fuel that could affect the supply of fish in the PT. Palu Jaya Utama. If the fishermen do not get diesel at the pump or in the merchant ecer then be unemployed fishermen for fishing and fish stocks for PT. Palu Jaya Utama also empty.

\section{AHP}

The decision making process is basically choosing a best alternative. As did the structuring issues, determination of alternatives, determination of possible values for categorical variables, the determination of value, preference requirements with respect to time, and the specification of the risk. However widening alternatives can be defined and assigned detail possible value, limitations remain a basis of comparison in the form of a single criterion. In solving the problem with an explicit logical analysis, there are three principles that underlie the thought of AHP, namely: the principle of preparing hierarchy, the principle of setting priorities, and principles of logical consistency.

Table 1.

\begin{tabular}{|l|l|l|l|}
\hline & Quality & Weather & Transport \\
\hline Quality & 1.0 & 7.0 & 9.0 \\
\hline Weather & 0.1 & 1.0 & 7.0 \\
\hline Transport & 0.1 & 0.1 & 1.0 \\
\hline Total & 1.3 & 8.1 & 17.0 \\
\hline
\end{tabular}

Table 2.

\begin{tabular}{|l|l|l|l|l|}
\hline & $\begin{array}{l}\text { Weathe } \\
\mathrm{r}\end{array}$ & $\begin{array}{l}\text { Qualit } \\
\mathrm{y}\end{array}$ & $\begin{array}{l}\text { Transpor } \\
\mathrm{t}\end{array}$ & $\begin{array}{l}\text { Weight } \\
\mathrm{s}\end{array}$ \\
\hline Rain & 0.73 & 0.22 & 0.05 & \\
\hline Dry & 0.36 & 0.30 & 0.25 & 0.34 \\
\hline $\begin{array}{l}\text { Types } \\
\text { of Fish }\end{array}$ & 0.12 & 0.25 & 0.21 & 0.20 \\
\hline $\begin{array}{l}\text { Fishing } \\
\text { Spot }\end{array}$ & 0.13 & 0.14 & 0.12 & 0.13 \\
\hline $\begin{array}{l}\text { Take } \\
\text { Fish }\end{array}$ & 0.09 & 0.07 & 0.11 & 0.09 \\
\hline Bacteria & 0.04 & 0.04 & 0.05 & 0.04 \\
\hline
\end{tabular}

\begin{tabular}{|l|l|l|l|l|}
1 & & & & \\
\hline Land & 0.04 & 0.04 & 0.05 & 0.04 \\
\hline Sea & 0.02 & 0.03 & 0.02 & 0.02 \\
\hline & & & & 1.00 \\
\hline
\end{tabular}

\section{Conclusion}

Indonesia is full of natural resources sector, especially the oceans as a beacon of economic development. Because Indonesia is known as one thousand island surrounded by a sea of Indonesian society is more dominant then the livelihoods of fishermen. Indonesia has the appeal of so many companies that invest and operate as a fish warehousing company.

There are several risks faced by fishermen or fish company, so the company must know the risks to be faced. Risks faced by fishermen or fish company that is weather, quality and transportation. The risk of making the price of fish to the hands of the public or the final consumer can be fickle. Fish prices rose sometimes meresakan community or the final consumer. For that by using Analytical Hierarchy Process (AHP) community or fish company can determine the risk dominant in influencing the price of fish up and down.

Having calculated using Analytical Hierarchy Process (AHP) turns highest risk weather that caused the fish price rises. The weather was $73 \%$

\section{Reference}

Rudi Prihantoro, 2012. KonsepPengendalianMutu, cetakanpertama, PT.RemajaRosdakarya Offset, Bandung.

RudiSuardi, 2004. SistemManajemenMutuISO 9000:2000, CetakanKetiga, CV TraunaGrafica, Jakarta.

MiruSulaeman,

Fatlina, 2007. ManajemenTransportasi, CetakanPertama, Tadulako University Press, Sulawesi Tengah.

DesrmawanRizky, 2005. Model KuantitatifPengambilanKeputusan\&PerencanaanStrategi, CetakanKesatu, ALVABETA CV, Bandung.

DarmawiHerman, 2004. ManajemenRisiko, CetakanKedelapan, BumiAksara, Jakarta

IndrajitEko,Richardus, 2002. KonsepManajemen Supply chain " CaraBaruMemandang Mata rantaiPenyediaanBarang", cetakankedua, PT GramediaWidiasarana Indonesia, Jakarta. 


\section{Chart of AHP (Analytic Hierarchy Process)}

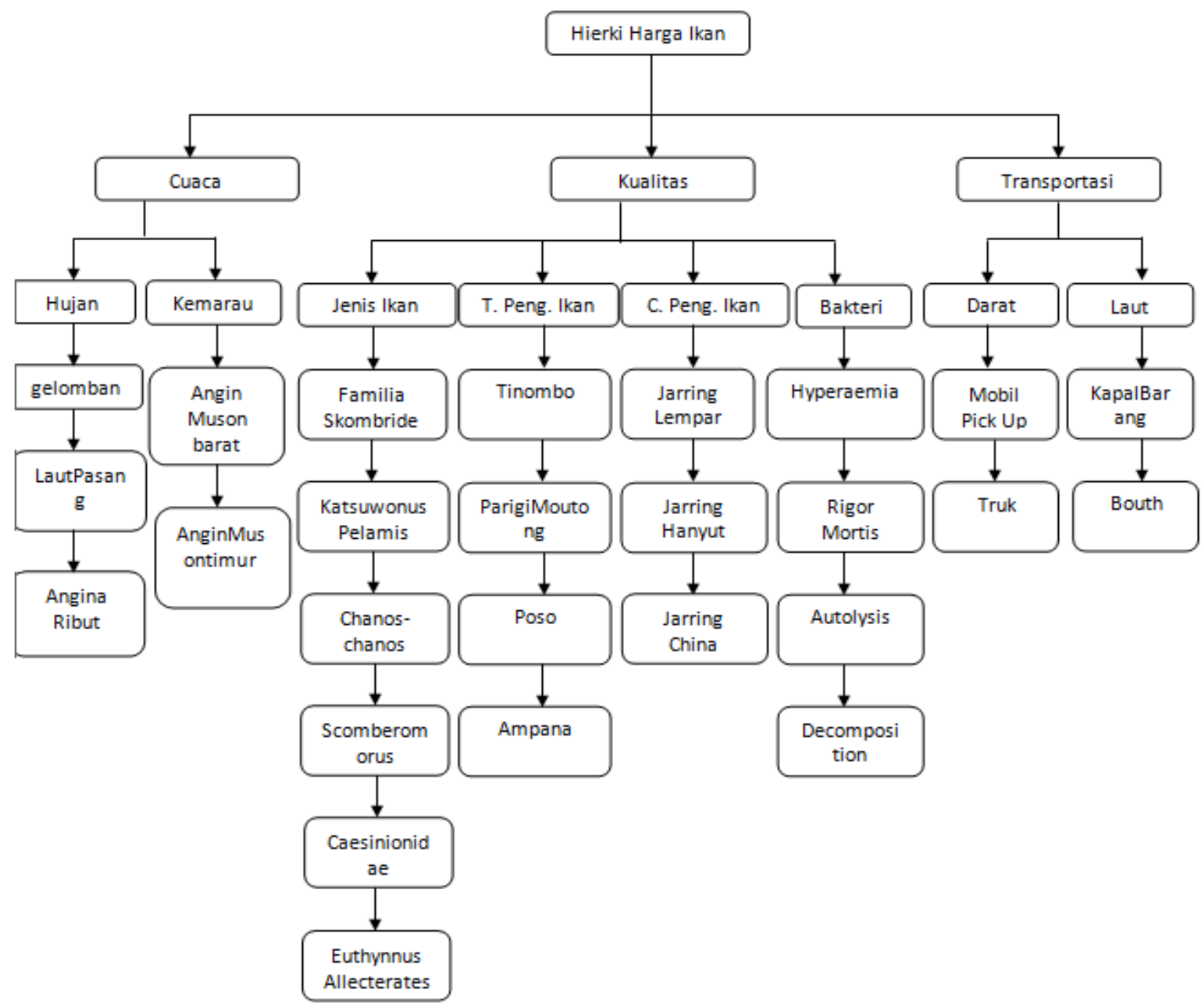

Keterangan:

1.1 The picture aboveis a chartof theAHP(Analytic Hierarchy Process). 
Table 1

The calculation ofAHP(Analytic Hierarchy Process) todeterminerisk.

\begin{tabular}{|c|c|c|c|}
\hline Risk & Weather & Quality & Transportation \\
\hline Weather & 1.00 & 7.00 & 9.00 \\
\hline Quality & 0.14 & 1.00 & 7.00 \\
\hline Transportation & 0.11 & 0.14 & 1.00 \\
\hline Total & 1.25 & 8.14 & 17.00 \\
\hline
\end{tabular}

Table 1.1

The calculation of averageAHP(Analytic Hierarchy Process) todetermine thegreatestrisk.

\begin{tabular}{|c|c|c|c|c|}
\hline Risk & Weather & Quality & Transportation & Average \\
\hline Weather & 0.80 & 0.86 & 0.53 & 0.73 \\
\hline Quality & 0.11 & 0.12 & 0.41 & 0.22 \\
\hline Transportation & 0.09 & 0.02 & 0.06 & 0.05 \\
\hline Total & 1.00 & 1.00 & 1.00 & 1.00 \\
\hline
\end{tabular}

Table 2

The calculation ofAHP(Analytic Hierarchy Process) inweatherto determine thecriteriamostat risk.

\begin{tabular}{|c|c|c|c|c|c|c|c|c|}
\hline Weather & Rain & Dry & Type of fish & Place fishing & How to make fish & Bacterium & Land & Sea \\
\hline Rain & 1.00 & 7.00 & 5.00 & 5.00 & 7.00 & 5.00 & 9.00 & 7.00 \\
\hline Dry & 0.14 & 1.00 & 3.00 & 5.00 & 5.00 & 5.00 & 5.00 & 9.00 \\
\hline Type of fish & 0.20 & 0.33 & 1.00 & 3.00 & 3.00 & 5.00 & 5.00 & 5.00 \\
\hline Place fishing & 0.20 & 0.20 & 0.33 & 1.00 & 7.00 & 7.00 & 5.00 & 9.00 \\
\hline How to make fish & 0.14 & 0.20 & 0.33 & 0.14 & 1.00 & 9.00 & 7.00 & 5.00 \\
\hline Bacterium & 0.20 & 0.20 & 0.20 & 0.14 & 0.11 & 1.00 & 3.00 & 3.00 \\
\hline Land & 0.11 & 0.20 & 0.20 & 0.20 & 0.14 & 0.33 & 1.00 & 9.00 \\
\hline Sea & 0.14 & 0.11 & 0.20 & 0.11 & 0.20 & 0.33 & 0.11 & 1.00 \\
\hline Total & 2.14 & 9.24 & 10.27 & 14.60 & 23.45 & 32.67 & 35.11 & 48.00 \\
\hline
\end{tabular}

Table 2.1 
The calculation of averageAHP(Analytic Hierarchy Process) inweatherto determine thecriteriamostat risk.

\begin{tabular}{|c|c|c|c|c|c|c|c|c|c|}
\hline Weather & Rain & Dry & Type of fish & Place fishing & How to make fish & Bacterium & Land & Sea & Average \\
\hline Rain & 0.47 & 0.76 & 0.49 & 0.34 & 0.30 & 0.15 & 0.26 & 0.15 & 0.36 \\
\hline Dry & 0.07 & 0.11 & 0.29 & 0.34 & 0.21 & 0.15 & 0.14 & 0.19 & 0.19 \\
\hline Type of fish & 0.09 & 0.04 & 0.10 & 0.21 & 0.13 & 0.15 & 0.14 & 0.10 & 0.12 \\
\hline Place fishing & 0.09 & 0.02 & 0.03 & 0.07 & 0.30 & 0.21 & 0.14 & 0.19 & 0.13 \\
\hline How to make fish & 0.07 & 0.02 & 0.03 & 0.01 & 0.04 & 0.28 & 0.20 & 0.10 & 0.09 \\
\hline Bacterium & 0.09 & 0.02 & 0.02 & 0.01 & 0.00 & 0.03 & 0.09 & 0.06 & 0.04 \\
\hline Land & 0.05 & 0.02 & 0.02 & 0.01 & 0.01 & 0.01 & 0.03 & 0.19 & 0.04 \\
\hline Sea & 0.07 & 0.01 & 0.02 & 0.01 & 0.01 & 0.01 & 0.00 & 0.02 & 0.02 \\
\hline Total & 1.00 & 1.00 & 1.00 & 1.00 & 1.00 & 1.00 & 1.00 & 1.00 & 1.00 \\
\hline
\end{tabular}

Table 3

The calculation ofAHP(Analytic Hierarchy Process) in qualitycriteria to determinethe mostat risk.

\begin{tabular}{|c|c|c|c|c|c|c|c|c|}
\hline Quality & Rain & Dry & Type of fish & Place fishing & How to make fish & Bacterium & Land & Sea \\
\hline Rain & 1.00 & 3.00 & 7.00 & 7.00 & 5.00 & 5.00 & 5.00 & 3.00 \\
\hline Dry & 0.33 & 1.00 & 9.00 & 7.00 & 5.00 & 7.00 & 7.00 & 5.00 \\
\hline Type of fish & 0.14 & 0.11 & 1.00 & 3.00 & 5.00 & 3.00 & 5.00 & 7.00 \\
\hline Place fishing & 0.14 & 0.14 & 0.33 & 1.00 & 7.00 & 5.00 & 7.00 & 9.00 \\
\hline How to make fish & 0.20 & 0.20 & 0.20 & 0.14 & 1.00 & 5.00 & 3.00 & 5.00 \\
\hline Bacterium & 0.20 & 0.14 & 0.33 & 0.20 & 0.20 & 1.00 & 3.00 & 3.00 \\
\hline Land & 0.20 & 0.14 & 0.20 & 0.14 & 0.33 & 0.33 & 1.00 & 5.00 \\
\hline Sea & 0.33 & 0.20 & 0.14 & 0.11 & 0.20 & 0.33 & 0.20 & 1.00 \\
\hline Total & 2.55 & 4.94 & 18.21 & 18.60 & 23.73 & 26.67 & 31.20 & 38.00 \\
\hline
\end{tabular}


Table 3.1

The Calculation of averageAHP(Analytic Hierarchy Process) in qualityto determine thecriteriamostat risk

\begin{tabular}{|c|c|c|c|c|c|c|c|c|c|}
\hline Quality & Rain & Dry & Type of fish & Place fishing & $\begin{array}{c}\text { How to } \\
\text { make fish }\end{array}$ & Bacterium & Land & Sea & Average \\
\hline Rain & 0.39 & 0.61 & 0.38 & 0.38 & 0.21 & 0.19 & 0.16 & 0.08 & 0.30 \\
\hline Dry & 0.13 & 0.20 & 0.49 & 0.38 & 0.21 & 0.26 & 0.22 & 0.13 & 0.25 \\
\hline Type of fish & 0.06 & 0.02 & 0.05 & 0.16 & 0.21 & 0.11 & 0.16 & 0.18 & 0.12 \\
\hline Place fishing & 0.06 & 0.03 & 0.02 & 0.05 & 0.29 & 0.19 & 0.22 & 0.24 & 0.14 \\
\hline How to make fish & 0.08 & 0.04 & 0.01 & 0.01 & 0.04 & 0.19 & 0.10 & 0.13 & 0.07 \\
\hline Bacterium & 0.08 & 0.03 & 0.02 & 0.01 & 0.01 & 0.04 & 0.10 & 0.08 & 0.04 \\
\hline Land & 0.08 & 0.03 & 0.01 & 0.01 & 0.01 & 0.01 & 0.03 & 0.13 & 0.04 \\
\hline Sea & 0.13 & 0.04 & 0.01 & 0.01 & 0.01 & 0.01 & 0.01 & 0.03 & 0.03 \\
\hline Total & 1.00 & 1.00 & 1.00 & 1.00 & 1.00 & 1.00 & 1.00 & 1.00 & 1.00 \\
\hline
\end{tabular}

Table 4

The calculation ofAHP(Analytic Hierarchy Process) in the transportto determinethe criteriamostat risk

\begin{tabular}{|c|c|c|c|c|c|c|c|c|}
\hline Transport & Rain & Dry & Type of fish & Place fishing & How to make fish & Bacterium & Land & Sea \\
\hline Rain & 1.00 & 3.00 & 3.00 & 3.00 & 3.00 & 3.00 & 3.00 & 7.00 \\
\hline Dry & 0.33 & 1.00 & 3.00 & 5.00 & 3.00 & 7.00 & 5.00 & 7.00 \\
\hline Type of fish & 0.33 & 0.33 & 1.00 & 5.00 & 7.00 & 9.00 & 3.00 & 7.00 \\
\hline Place fishing & 0.33 & 0.20 & 0.20 & 1.00 & 3.00 & 7.00 & 5.00 & 9.00 \\
\hline How to make fish & 0.33 & 0.33 & 0.14 & 0.33 & 1.00 & 7.00 & 5.00 & 9.00 \\
\hline Bacterium & 0.33 & 0.14 & 0.11 & 0.14 & 0.14 & 1.00 & 3.00 & 5.00 \\
\hline Land & 0.33 & 0.20 & 0.33 & 0.20 & 0.20 & 0.33 & 1.00 & 7.00 \\
\hline Sea & 0.14 & 0.14 & 0.14 & 0.11 & 0.11 & 0.20 & 0.14 & 1.00 \\
\hline Total & 3.14 & 5.35 & 7.93 & 14.79 & 17.45 & 34.53 & 25.14 & 52.00 \\
\hline
\end{tabular}


Table 4.1

The calculation of averageAHP(Analytic Hierarchy Process) in the transportto determinethe criteriamostat risk.

\begin{tabular}{|c|c|c|c|c|c|c|c|c|c|}
\hline Transportation & Rain & Dry & Type of fish & Place fishing & How to make fish & Bacterium & Land & Sea & Average \\
\hline Rain & 0.32 & 0.56 & 0.38 & 0.20 & 0.17 & 0.09 & 0.12 & 0.13 & 0.25 \\
\hline Dry & 0.11 & 0.19 & 0.38 & 0.34 & 0.17 & 0.20 & 0.20 & 0.13 & 0.21 \\
\hline Type of fish & 0.11 & 0.06 & 0.13 & 0.34 & 0.40 & 0.26 & 0.12 & 0.13 & 0.19 \\
\hline Place fishing & 0.11 & 0.04 & 0.03 & 0.07 & 0.17 & 0.20 & 0.20 & 0.17 & 0.12 \\
\hline How to make fish & 0.11 & 0.06 & 0.02 & 0.02 & 0.06 & 0.20 & 0.20 & 0.17 & 0.11 \\
\hline Bacterium & 0.11 & 0.03 & 0.01 & 0.01 & 0.01 & 0.03 & 0.12 & 0.10 & 0.05 \\
\hline Land & 0.11 & 0.04 & 0.04 & 0.01 & 0.01 & 0.01 & 0.04 & 0.13 & 0.05 \\
\hline Sea & 0.05 & 0.03 & 0.02 & 0.01 & 0.01 & 0.01 & 0.01 & 0.02 & 0.02 \\
\hline Total & 1.00 & 1.00 & 1.00 & 1.00 & 1.00 & 1.00 & 1.00 & 1.00 & 1.00 \\
\hline
\end{tabular}

Table 5

The resultsaweights AHP (Analytic Hierarchy Process)

\begin{tabular}{|c|c|c|c|c|}
\hline \multirow{2}{*}{ Risk } & \multicolumn{3}{|c|}{ Objektif } & \multirow{2}{*}{ Weights } \\
\cline { 2 - 5 } & Wearther & Quality & Transportation & \multirow{2}{*}{0.34} \\
\cline { 2 - 5 } & 0.73 & 0.22 & 0.05 & 0.20 \\
\hline Rain & 0.36 & 0.30 & 0.25 & 0.12 \\
\hline Dry & 0.19 & 0.25 & 0.21 & 0.13 \\
\hline Type of fish & 0.12 & 0.12 & 0.19 & 0.09 \\
\hline Place fishing & 0.13 & 0.14 & 0.12 & 0.04 \\
\hline How to make fish & 0.09 & 0.07 & 0.11 & 0.04 \\
\hline Bacterium & 0.04 & 0.04 & 0.05 & 0.02 \\
\hline Land & 0.04 & 0.04 & 0.05 & 1.00 \\
\hline Sea & 0.02 & 0.03 & 0.02 & \\
\hline
\end{tabular}

